\title{
Research of Satisfaction of Quality of Educational Results from the Viewpoint of Education Services Consumers
}

\author{
Volha Paulava ${ }^{1, *}$, Alla Nerubasska ${ }^{2}$, Inna Kuzmenko $^{3}$, Tetiana Yamilova ${ }^{4}$, Liudmila Zahorodnia $^{4}$ \\ ${ }^{1}$ Department of Philosophy, Odesa National Maritime Academy, Odessa, Ukraine \\ ${ }^{2}$ Department of Philosophy, Odesa I. I. Mechnikov National University, Odessa, Ukraine \\ ${ }^{3}$ Department of General and Clinical Pathophysiology, Odesa National Medical University, Odessa, Ukraine \\ ${ }^{4}$ Department of Professional Pathology and Functional Diagnostics, Odesa National Medical University, Odessa, Ukraine
}

Received June 10, 2020; Revised June 20, 2020; Accepted July 15, 2020

Copyright $\bigcirc 2020$ by authors, all rights reserved. Authors agree that this article remains permanently open access under the terms of the Creative Commons Attribution License 4.0 International License

\begin{abstract}
The purpose of the research was to prepare recommendations for the academic philosophy and academic teaching community on achievement of a high degree of satisfaction with the quality of educational results in humanities (with philosophy taken as an example) among students of non-humanities professions. For this purpose, we have studied the phenomenon of satisfaction with the quality of the educational results in the Ukrainian market of education services. The research was carried out since November 2018 till March 2020. In our work, we relied on theoretical and practical conclusions of American, European and Ukrainian researchers of the phenomenon of satisfaction with education services. The research interest of our multidisciplinary team was focused on specific aspects of teaching at the technical and medical higher educational institutions in Odessa, Ukraine. The theoretical aspect of the work is focused on clarification of the concepts of "educational results", "quality of the educational results", "practice orientation" in teaching philosophy for non-humanities professions (marine engineers, healthcare workers, etc.). The empirical part of the work is important for improvement of the educational programs in the area of humanities taught at non-humanities higher education institutions in order to enhance their quality and competitive ability in the market of education services. This work resulted in formulation of recommendations for the academic philosophers and academic teacher community and stakeholders (owners of education services), students of non-philosophical professions with possibility of their integration into the education services provision process.
\end{abstract}

Keywords Education Services, Market of Education Services, Educational Results, Diagnostics of the Educational Results, Satisfaction with the Educational
Results, Practice Orientation in Teaching Humanities

\section{Introduction}

This research is a planned, system, evaluation, and corporate effort as part of the multidisciplinary project aimed to assess the quality of education services which was performed from November 2018 to March 2020 at the Odessa National Maritime Academy, Odessa National Medical University and Odessa I. I. Mechnikov National University. The team of the authors who worked on the analysis of the research hypothesis is from the united teacher community of Odessa. It is essential that the team unites teachers of humanities and natural science disciplines. The general idea of this research came to the work group of teachers of philosophy and other humanities for students in non-humanities fields in late 2017 and early 2018 in connection with the fundamental changes in understanding of the education services quality introduced by the Higher Education Law of Ukraine of July 1, 2014 (No. 1556-VII). Our research group worked on the general plan of the research from January to October 2018 and implemented it in practice from the end of 2018 to the end of 2019. The stage of final conclusions lasted from the end of 2019 to the end of April 2020. The research process does not consider the factor of "pandemic" education and transfer of education services to online format, as the general practical studies had been completed before the introduction of the containment measures in Ukraine. Our research group is really interested in and will consider the importance of inclusion of the data on students' satisfaction with online education in the process 
of future research.

So, the original hypothesis was formulated by the work group as follows: the level of satisfaction with the quality of educational results in humanities among students of non-humanities professions depends on the quality of the education services. In particular, it is important, that the teacher should focus on the practical value of ultimate competencies (soft skills).

In this research the authors collected updated empirical data on satisfaction with the results of education services in the area of humanity sciences (in particular, philosophy) from the perspective of students of non-humanities professions in certain higher education institutions in Odesa (Ukraine). The authors have formulated a number of substantial recommendations at different levels for enhancement of the competitive ability of the philosophy education programmes in the Ukrainian market of education services.

\section{Methods}

\subsection{General Information}

The research was carried out as a system, collaborative study of the Ukrainian market of education services within the framework of a long-term pedagogical project for improvement of the quality of education services since November 2018 till March 2020. The team of authors who worked on this research is a part of the permanent united teacher community of Odessa. The research sites were the Odessa National Maritime Academy, Odessa National Medical University and Odesa I.I. Mechnikov National University. In the theoretical and practical parts, the authors proceeded from the earlier published articles on education services and students' satisfaction $[6,19,20,25$, 30]. The empirical part of the research focuses on monitoring of the dynamics of the young and transforming market of education services in the Ukraine.

The object of the study is the quality of education services in the southern region of Ukraine.

The subject of the study is the phenomenon of satisfaction with the quality of educational results from the perspective of domestic consumers of the education services (students).

The purpose of the study is to prepare recommendations for the academic philosophy and academic teaching community on achievement of a high degree of satisfaction with the quality of educational results in humanities (with philosophy taken as an example) among students of non-humanities professions.

The following research methods were used in the study: methods of theoretical analysis (induction and deduction; comparative and retrospective analysis; classification; specification and generalization) and empirical methods (study scientific papers; content analysis of relevant sources; monitoring of research publications).

\subsection{Three Stages of the Empirical Study}

The research architecture consisted of three stages:

- $\quad 1^{\text {st }}$ stage: literature review, analytics and collection of statistical data. Upon completion of the literature review we able to state the research goal which was verified at the next stage;

- $2^{\text {nd }}$ stage: implementation of the quantitative sociological method;

- $\quad 3^{\text {rd }}$ stage: summing up the research results, analysis of the experiment data, and assessment of achievement of the planned goal of the research.

The methodological basis of the research is general scientific methods and principles of cognition, historical cultural and comparative analysis of education services used in the research of the phenomenon of satisfaction with educational results in philosophy from the perspective of students of non-humanities higher educational institutions. The empirical basis of the research was the accumulated statistical data on the students' responses collected by way of questioning and sociological statistical processing.

\subsection{Method of the Empirical Study}

The $2^{\text {nd }}$ stage of the research was of empirical nature and consisted of relatively independent phases. The $1^{\text {st }}$ preparatory phase included development of the program of empirical studies; identification of the work groups for specific higher education institutions located in the southern region of Ukraine; definition of the research populations which included 148 persons; determination of the research tools (interviews, questionnaires). During the second stage of the empirical studies, the investigators collected data by way of personal interview combined with questioning in the predefined sample of respondents. An interim adjustment and control of preliminary data (initial control).

The $3^{\text {rd }}$ phase of the empirical study included processing and interpretation of the interview and questioning data; generation of electronic empirical sample databases; and analysis of the final results. Control of the sample statistical parameters was performed on the basis of comparison of the basic parameter of the actual sample with the pre-defined (control) one using MS Excel 2010 (as a standard application to MS Office). As a result we've got descriptive statistics with a linear distribution of the responses. The primary indicator in the control group is the variable to be diagnosed - the practical value of learning results in philosophy". We consider this diagnostic variable as subjective assessment by the domestic consumers of education services, as an indicator of balance between the demands (requests, expectations) and the degree to which they have been finally achieved.

And, finally, after discussion, the authors have 
formulated their conclusions.

\section{Literature Review}

We were monitoring the publication activity on the research issue throughout the research period. The final literature on this issue contains 32 publications, including articles in journals indexed in databases WoS and SCOPUS. In order to increase reliability of the research a decision was made to perform monitoring of publication activity separately in two directions which constitute an integrated view of the issue.

First, to assess activity of the study of the phenomenon of the quality of educational results, specifically, what this term is understood to be and how achievement of specific appropriate educational results in humanities can be assessed using modern methods, in particular, in the process of teaching philosophy for students in non-humanities fields. Second, to review publications on satisfaction or dissatisfaction with the educational results from the perspective of education services consumers.

\subsection{Assessment of the Publication Activity on the Issue of Diagnostics of Quality Educational Results}

The review of the major literature sources referred to in this article shows an increase in academic interest to these issues. So, the literature review on the issue of diagnostics of quality educational results includes above 10 publications, for example, articles $[1-3,9,10,12,14,15$, $17,22,28,29,32]$.

\subsection{Assessment of the Publication Activity on Achievement of Satisfaction with Educational Results}

The literature review on achievement of satisfaction with educational results includes 10 publications in journals indexed in databases WoS and SCOPUS, for example, articles $[4,5,7,8,11,13,18,21,23,24]$. The review of the major literature sources referred to in this article shows deficiency and complexity of practical assessments relating to the phenomenon of satisfaction of the educational results in humanities (in particular, philosophy) among students of non-humanity professions. Since the issue is of immediate practical importance for achievement of competitive advantages by non-humanities higher education institutions in the market of education services, therefore the in-depth study of this issue is justified, and consideration of the study results in development of education programmes for humanities studies of the philosophic cycle may contribute to substantial improvement in the quality of the education services in future.

\subsection{The Phenomenon of Quality of Education Services and Its Content Interpretations in the Last Decade}

This conclusion number 1 made in our work requires discussion. Namely, most contemporary researchers of the higher education system, including us, are convinced that the main purpose of reproduction of high quality education process is to achieve the pre-defined quality results through the use of flexible modern intensive education technologies. Therefore, in this work we assume that timely assessment of satisfaction or dissatisfaction with educational results will allow improving the quality of the education performance based on its measurability as defined by the European education standards and will help the teachers to correlate their teaching efforts with demands of the stakeholders, i.e. the parties interested in high quality educational results as defined by the international quality standards ISO / IES 29148: 2011.

In the first part of the discussion, we focused on theoretical clarification of the philosophic content of the phenomenon of the quality of educational results and of the need of methodological search for effective tools for improvement of the quality of learning of philosophic disciplines (namely: philosophy, critical thinking, logics, argumentation in social communications, rhetoric and other) taught to students of non-humanities professions.

In recent years the concept of "educational result" is considered in the pedagogical, managerial, economic and qualimetric contexts. However, the current level of theoretical and methodological comprehension of the issue is insufficient to meet the demands of the education practice. From the theoretical perspective concretization of the qualitative constituent of the educational result remains relevant. In order to correct and clarify the definition of the term "educational result" let's refer to philosophical measurement of the paradigm of higher education quality. There is a popular belief among our domestic scientists that the contemporary higher education system in Ukraine is process-oriented rather than result-oriented. Therefore, this system requires a serious "reboot" in order to review the quality orientation of the result. In European countries the issue of the essence of educational result relates to the technologies for ensuring compliance with the education standards. The blurry definition of the education result is indicative of both the novelty and practical implications of its qualimetric evaluation.

Classically, the essence of the concept of "quality", specifically the quality of life including the quality of education has dual interpretation: a subjective constituent as personal satisfaction with high quality result and an objective constituent as social consumer effectiveness.

Since the concept of education quality is, in broad sense, associated with education institutions' performance standards, in our scientific studies of the phenomenon we reviewed conclusions related to organization and operation of the quality assurance systems of higher education institutions which are accumulated in the following 
documents: the Law of Ukraine on Higher Education [16], the Standards and Guidelines for Quality Assurance in the European Higher Education Area (ESG), 2015 [29], Analytical Review. "Higher Education in Ukraine: Agenda for Reforms", 2017-2018 [2], Higher Education and Science: Scientific and Analytical Review, 2018 [31], information and analytical review "Development of the higher education quality assurance system in Ukraine" [32]. We also analyzed the map-based monitoring of quality of higher education [9].

The Law of Ukraine on Higher Education explains the meaning of two concepts: the quality of higher education quality and the quality of education activity, with the integral competence of the higher education seeker at a certain level being recognized as the learning result [16].

The authors of the analytical review "Higher Education in Ukraine: Agenda for Reforms" believe that "in general, the internal quality assurance system in the higher education institutions should include two key components: students' assessment of the quality of education performance at the respective education institutions and rating of the academic teaching staff in terms of research and education performance" [2, p. 33]. The rating assessments of the academic teaching staff on the self-assessment basis have been performed for several years, and their mechanism has a definite structure.

In terms of the competency-based approach, the quality is also associated with conformity with the labor market requirements or, more specifically, with those of the stakeholder consumers. This suggests that the vector of quality essence modernization shifts to the sphere of pragmatic selection and this phenomenon is increasingly economic in nature. That's why the interpretation of education quality becomes more focused on the system management context, and the component of consumer satisfaction with education services becomes essential.

Therefore we think it is possible to speak about changes in understanding efficiency of the contemporary education model. In particular, we can see a transformation of the content of the education quality concept. It acquires a new sense, and the direction for the entire education process is set out by the quality of educational results. From the perspective of quality all the parties concerned (higher education seeker, stakeholders, teachers, governmental and non-governmental agencies, approval authorities, etc.) can integrate their expectations and demands into the system. In contrast to the conventional knowledge-based model which was built on the "input" parameters (learning purpose, content, etc.), the competence-based education model is focused on satisfaction with the quality of provided education services among their consumers, i.e. students.

As a matter of clarification, according to the Law of Ukraine on Higher Education the integral competency consists of general and special (professional) competencies and is considered as a "generalized description of the qualification level which demonstrates basic characteristics of the competence level in terms of learning and/or professional activity", where certain "general competencies - as universal ones do not depend on subject-matter disciplines, but are importance for further successful professional and social activity of the seekers in various fields and for their personal development" [16]. Therefore the updated education quality paradigm is aimed not only at building a set of professional competencies, but also at development of general soft skills competencies where the personal creative potential in combination with the culture of critical thinking is of key importance.

\section{Results}

The literature review performed in this research brings us to the following conclusions which are not rigorous but require thorough discussion and confirmation in the empirical part of the research.

\subsection{Changes in the Area of Diagnostic Assessment of the Quality of Educational Results in the Ukrainian Segment of Higher Educational Institutions.}

We studied this assumption using the method of theoretical literature review. We found that there is quite a worrying symptom that "Ukraine is in the bottom ten in the global rating for the quality of university education"! [10]. Although, according to the Ukrainian Institute for the Future, there were 289 higher educational institutions in the country with $133 \mathrm{mln}$ of students by the beginning of 2018 [10, p.9]. "Absence of the independent system for higher education quality assessment" (in fact, it is being actively developed right now), and substantial gap between the education programmes, labour market demands and main trends of the Fourth Industrial Revolution are listed in the Report among the most critical deterrents to the development of the higher education system [10, p. 11]. For example, there is a reference to the new research performed by the McKinsey Global Institute (US), according to which one-third of jobs in the USA can be lost to automation by 2030 due to labor automation. Klaus Schwab, the Executive Chairman of the World Economic Forum in Davos, notes in his new book "The Fourth Industrial Revolution, Shaping the Fourth Industrial Revolution" that large business-corporations have an impact on education. The author places the emphasis on the problem of shortage of future skills and need for new professional competencies such as ability to cooperate, listening skills [27].

We think that these worrying indicators point to emergence of new challenges for our domestic higher education system.

Today the concept of higher education efficiency has been updated and complicated to a significant extent. A decade ago, most people were convinced that holding a 
diploma of higher education was of critical importance! Nowadays young people do not want to spend financial, time, and personal resources to acquire any education. One of the higher education seeker's basic requirements is high quality of higher education.

Keeping the European specifics of the development of the national education standards in mind, we would like to draw your attention to intensification of the axiological interpretation of the education efficiency which implies that the actual high quality result is a multicomponent value being created for the long run and is associated with certain risks.

The summary review of the most significant literature sources on this subject over the past five years we performed as part of our research showed that a substantial theoretical basis has been created for understanding the phenomenon of competency and its historical and cultural role in achievement of education quality. However, the issues of diagnostic assessment of the learning result level in the higher education institutions still remain quite complicated and problematic. Most researchers note that the advantage of the competency-based approach as compared to the conventional knowledge-based approach is that the final education outcome is an integrated indicator of the personality development quality rather than the totality of the acquired knowledge.

The most important thing in the competence-based approach is specific profession-oriented skills supplemented by a set of general universal competencies rather than general awareness of the education seeker. That's why the quality education system must provide not only reliable profession knowledge background of the future specialist in specific area but also development of the personality aimed at life-long self-development and training for which there is a competitive demand in the labour market. This is an obvious advantage of the education innovation which is being actively adapted to the Ukrainian education practice now.

The changes currently needed should be aimed at "bringing up" and "cultivation" of a creative person, because mechanical recursive actions and reproductive style of thinking have already been assimilated by the artificial intellect.

Of particular note is that today the general competencies for a specific profession are selected with a focus on the profession, but practically at random without conceptual view to the immediate prospects of the development of the respective knowledge area. We understand that each teacher faced fragmentarily instead of systematization in achievement of practical results in teaching a specific discipline and disassociation of interdisciplinary links!

In our search for adequate diagnostic technologies which could contribute to measurement of so, called soft skills competencies and promote smoothly transformation of the educational programs towards achievement of the appropriate standardized result we analyzed the conclusions of the Education 2030 International Project.
The project extends the focus to the system of competencies within the triad "knowledge - skills values". By declaring the OECD-2030 education principles its authors note that specialists of the future first "have to be systems' thinkers" [1].

Traditionally, it is usual to distinguish effectiveness of current learning in the educational practice, to record it using respective number of scores in the lessons by means of oral or written check. The test- and examination-based registration of the training level of higher education seekers is still important. In these cases the teacher is governed by respective testing and examining regulations and forms provided for by the quality assurance system of the specific educational institution.

The analysis of the available global practices in diagnostic assessment of the quality of educational results as part of the competency-based approach shows that there are several relatively independent paths to address the problem.

The first one is the European approach which is predominantly applied by Germany and France. Its distinctive features are comprehensiveness and multidimensionality of the solution to this problem. The assumption prevailing in the European educational practice which is built on dynamic standards of the quality of education services is that immediate assessments of competencies are impossible. However, it is possible to perform diagnostic measurements of the levels and degrees of the educational results maturity. For instance, PISA, the global education quality assessment project, was planned as a three-year cycle. By the way, PISA-2018 is the first research cycle with participation of Ukraine. This international programme is built on the measurement of competence-based indicators. It is stated in the summaries of the $48^{\text {th }}$ Meeting of the PISA Governing Board in the context of its mission that "in this research the focus is placed on the application of knowledge in real life situations and on the use of detailed questionnaires of the test participants which allow studying the impact of various socio-economic and personality factors, as well as the the teaching environment on the education success" $[26$, p.3].

The second solution path is the experience of the USA which is a founder of the traditions of assessment of the quality of educational results with the focus placed on the psychological content-analysis of behavioral strategies of an individual trying to reach a definite result. The group of authors including B. Trilling, Ch. Fadel and others, has designed a project on the basis of the systematized set of competencies "4D-education" (four-dimensional education) [27]. A 4D education space was modeled where knowledge, skills and the temper of a person were designed with respect to the meta-cognition space, i.e. on the basis of proactive metacognitive teaching strategies.

Third, one of qualitative indicators of the specified goal achievement is higher education seekers' satisfaction, i.e. the students' satisfaction with the teachers' work. We 
understand that the degree of satisfaction with the quality of education services is a highly dependent multifactorial indicator, the satisfaction level may be influenced by a number of objective and subjective factors. We do not discuss this question in this article; we just focus on the methods for internal assurance of the quality of education services in compliance with the European standards and recommendations. We would like to emphasize that our joint pedagogical group has got interested in the poorly studied problem of attainment of the high level of satisfaction with the quality of educational result in humanities among students of non-humanities professions. That was the purpose of the empirical part of the research.

\subsection{Assessment of the empirical result of the completed research}

The result we have arrived at in practice in the course of the research performed by the team of authors is the organized of consumer monitoring of satisfaction with the quality of the obtained educational result. We emphasize that we studied specifically "satisfaction with the quality of educational result" as the concept of "satisfaction with education services" is quite loose and unspecific and consequently inefficient for the proposed practical recommendations. Consequently, the indicative power for the parameter of "satisfaction with the quality of educational results" for a specific discipline (philosophy in our case) is much higher.

The primary data collection system was organized on the basis of interviews and questioning of domestic consumers of education services (students) (Appendix 1).

In order to perform a diagnostic assessment of satisfaction with the obtained educational results we have intentionally chosen the most complex analysis variant, namely, indicators of satisfaction with the attained educational result in studying humanities, in particular, philosophy, by students of non-humanities professions (technical - marine engineers and natural science healthcare workers).

The students were divided into two groups: experimental (subject to diagnostic assessment, with inclusion of the assessed element) and control (without inclusion of the variable to be diagnosed). The main measurement parameter in this method is the level of satisfaction with educational results from the education course in philosophy among the students of non-humanities professions.

Interviews and questionnaires were based on three parameters: I - "encouragement of students in the process of attaining educational results, stimulation of motivation and self-analysis in attaining educational results", II "transparency and availability of the planned learning results for the course", III (diagnosed variable) "practical value of the educational results of the course of philosophy" which were assessed by the students according to three standards. In accordance with the
European guidelines the term "standard" means: A satisfied (on a percentage basis); B - not satisfied (on a percentage basis); C - I doubt (don't understand the question).

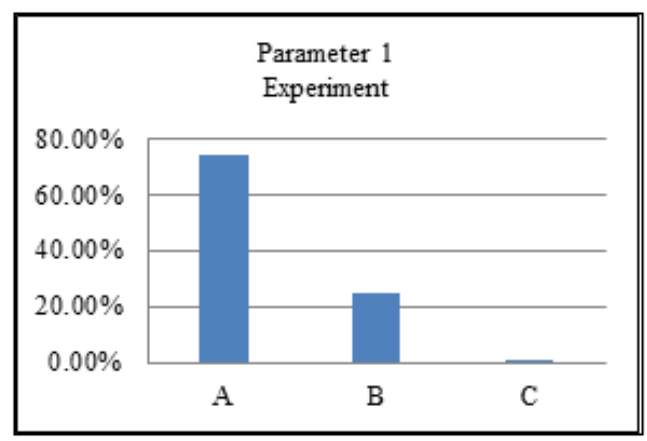

Figure 1. Parameter I measurements ("encouragement of students in the process of attaining educational results, stimulation of motivation and self-analysis in attaining educational results), experimental group, $\%$

According to Fig. 1, in the experimental group (with inclusion of the assessed element - "practical value of the educational results of the course of philosophy"): for parameter I "encouragement of students in the process of attaining educational results, stimulation of motivation and self-analysis in attaining educational results" the percentage ratio of the standards (A, B, C) was found as: $74 \%, 25 \%, 1 \%$.

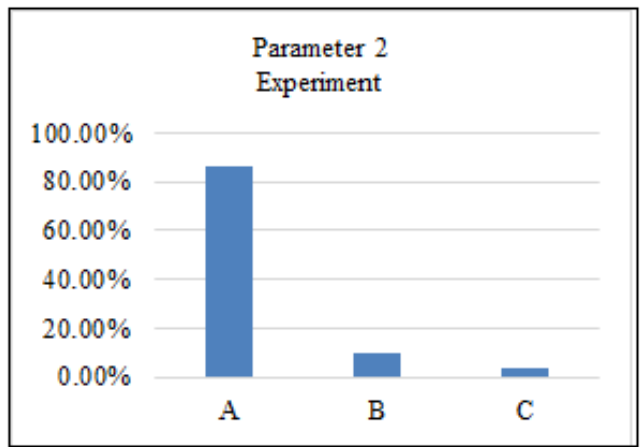

Figure 2. Parameter II measurements ("transparency and availability of the planned learning results for the course"), experimental group, $\%$.

Data of Fig. 2 confirm that for parameter II "transparency and availability of the planned learning results for the course» the percentage ratio of the standards (A, B, C) was found as: $86 \%, 10 \%$, and $4 \%$.

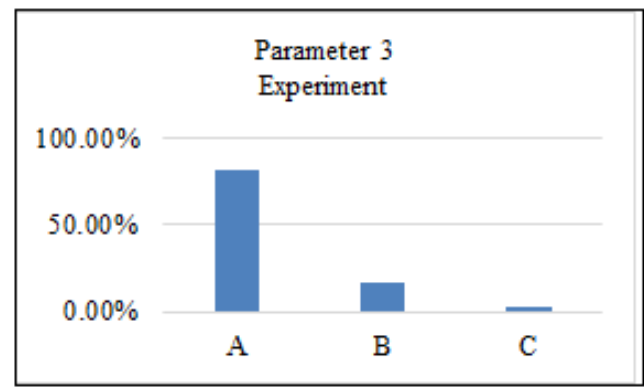

Figure 3. Parameter III measurements ("practical value of the educational results of the course of philosophy"), experimental group, $\%$. 
Data of Fig. 3 confirm that for parameter III (diagnosed variable) - "practical value of the educational results of the course of philosophy" the percentage ratio was: $81 \%$, $16 \%$, and $3 \%$.

In the control group (without inclusion of the variable to be diagnosed - "practical value of the educational results of the course of philosophy") the statistical results were as follows:

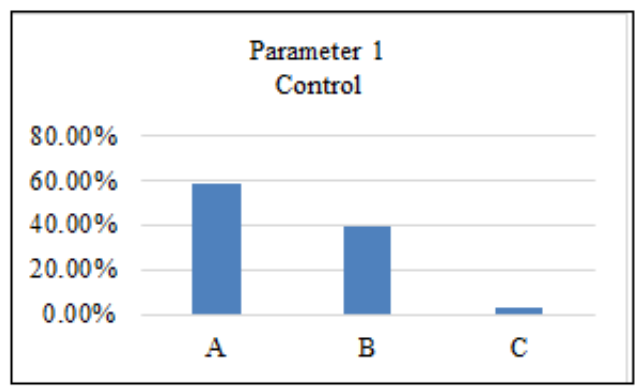

Figure 4. Parameter I measurements ("encouragement of students in the process of attaining educational results, stimulation of motivation and self-analysis in attaining educational results), control group, $\%$

According to Fig. 4, the statistical results for parameter I were as follows $-58 \%, 39 \%, 3 \%$ (A, B, C respectively).

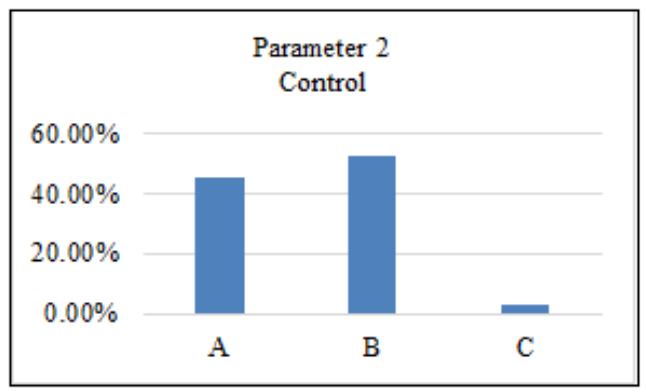

Figure 5. Parameter II measurements ("transparency and availability of the planned learning results for the course"), control group, $\%$.

According to Fig. 5, the statistical results for parameter II were as follows $-45 \%, 52 \%, 3 \%(\mathrm{~A}, \mathrm{~B}, \mathrm{C})$.

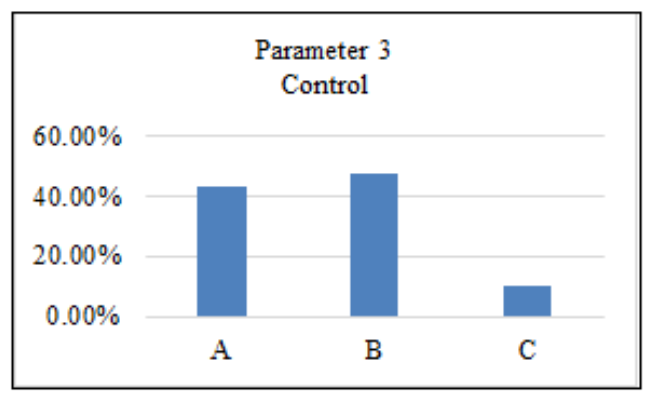

Figure 6. Parameter III measurements ("practical value of the educational results of the course of philosophy"), control group, $\%$.

According to Fig. 6, the statistical results for parameter III were as follows $-43 \%, 47 \%, 10 \%$ (A, B, C).

The resulting graphical representation of the collected data presented in diagrams 1 to 6 demonstrates that the level of satisfaction with the educational results among the students in these two (control and experimental) groups was essentially different. The survey data confirm that students of non-humanities professions (marine engineers and healthcare workers) demonstrated sustainable interest in philosophy when the teacher consciously and intentionally maintained motivation for achievement of practice-oriented soft skills specific to the respective professions throughout the course.

In the control group, where the philosophy teacher was not oriented to the profession-specific result the students' satisfaction dropped. For parameters II and III the percentage was lower that dissatisfaction with the course results! These are very impressive and warning results! The data show that contemporary students of non-humanities professions don't want to waste their time and efforts for acquiring knowledge which is "of little use" from the professional perspective. Achievement of high level professional competencies is a strong driver for soft skills development. Consequently, the ideological constituent of humanity disciplines, in particular, in teaching the course of philosophy becomes much weaker.

Therefore, the collected empirical data presented in form of the graphical diagrams suggest with a high degree of certainty that the level of satisfaction with the achieved educational result on the course of philosophy for non-humanities professions are highly dependent on their practice-orientation, usefulness and applicability in their future profession. If this diagnosed element is not taken into account, the students demonstrated moderate interest in achievement of the educational result for the course of philosophy and practically half of the control group respondents were not satisfied with the educational result of the course!

If the results of these studies are considered and implemented in the teaching practice in development of education programmes for humanity disciplines related to philosophy - this may lead to obvious expected improvement of the quality of education services in future. Therefore, the interdisciplinary pedagogical data obtained in course of the experiment are of essential importance for improvement of competitive advantages of non-humanities higher education institutions in the market of education services, since they demonstrate one of the ways to improve satisfaction with the quality of the attained results among consumers of education services.

\section{Discussion}

Over the last decade the phenomenon of quality of education services and especially the quality of the educational results is in the focus of the scientific philosophical and pedagogical analysis. The adaptation of the competency-based approach by the Ukrainian system of higher education is associated with changes in the content-related interpretations of the concept of educational result. So, the focus shifts from the 
knowledge-based education component to development of the resulting competencies: a set of hard and soft skills. Consequently, the ultimate educational result is an integrated parameter of quality of personality development in the profession.

The problem of diagnostic analysis of the quality of educational results, especially assessment of the level of soft skills development in terms of the competency-based approach remains highly relevant. The completed research shows deficiency of mechanisms for assessment of the development level of soft skills educational results in the existing international and domestic educational practice. Therefore, it is necessary to consider generation of a new system for the control of achievement of competencies maturity (especially soft skills) in accordance with the relevant international standards.

In the assessment of attainment of the educational results in terms of the competence-based model, both the quantitative (knowledge-based) and qualitative (including, first of all, the degree of satisfaction with the achieved educational result from the perspective of the domestic consumers of education services, i.e. the students) parameters are of high importance. In this research we have experimentally explained the importance of practical orientation of the educational results to professional applicability of knowledge obtained in the process of reaching humanities (as exemplified by philosophy) for students of non-humanities professions. The graphically presented responses of many students confirm that their interest in a practice-oriented humanities learning model is much higher.

\section{Conclusions}

In view of the above let us sum up and formulate a number of theoretical and practical recommendations for researchers in the area of education, practicing teachers as carriers of the education services, owners and consumers of these services (students, employers, parents, and so on), because the external parameters such as the processes of integration and harmonization of the Ukrainian education system with the European standards have actualized significantly the issue of the educational results quality. The internal parameters such as conscious expectations of students and owners of the education services demonstrate an increase in their interest in high quality education results.

1. Therefore we recommend that the academic philosophers community should further develop this area of theoretical studies and achieve the existing loose understanding of the phenomenon of high-quality education results (in the area of philosophy, law, economy, management, qualimetry, etc.) for satisfaction of education services consumers.

2. We recommend that the academic philosophers community should be more and persistently focused on the results of practical value relevant to the students' professional orientation in the process of building a model of teaching humanities (e.g. philosophy) for students of non-humanities professions.

3. We recommend that the stakeholders should intensify the expert assessment of the educational programmes and consider inclusion of the soft skills development process into the existing humanities courses. They should be clearly oriented to respective profession and connected with the hard skills development.

So, the research aim has been achieved. We hope that this will help philosophy, logics and other fundamental humanities to revise and enhance their education potential as a social and cultural compass aimed towards the good, humanism, effectiveness and adaptability to crises.

The purpose of the research activities planned for the immediate future is to study the phenomena of satisfaction and dissatisfaction (both quantitative and qualitative components) with online and offline education services.

\section{Acknowledgements}

The authors would like to thank the reviewers for their useful comments on the article. 


\section{Appendix 1}

\section{QUESTIONNAIRE for Non-Humanities Students}

\section{TOPIC: THE LEVEL OF SATISFACTION OF NON-HUMANITIES STUDENTS WITH THE RESULTS OF THE TRAINING COURSE "PHILOSOPHY",}

Questionnaire explanations: In accordance with European standards and recommendations: "University quality assurance policy is based on the principles of publicity and maintaining a culture of quality. Creating a favorable and effective learning environment for students requires evaluation of program content, study load, needs of society, expectations, student satisfaction and achievement level" [2].

The main indicator of assessment is the cadet's satisfaction with the training course "Philosophy"

* Standards are a measure of a cadet's satisfaction with the components of the course:

satisfied / dissatisfied / did not understand

(it is possible to indicate \% satisfaction or dissatisfaction and explain why)

\begin{tabular}{|c|c|c|}
\hline $\begin{array}{l}\text { Components } \\
\text { (indicators evaluated by the cadet) }\end{array}$ & $\begin{array}{c}\text { Standards } \\
\text { (measure of satisfaction with the components } \\
\text { of the course) / specify in } \%\end{array}$ & $\begin{array}{c}\text { Recommendations } \\
\text { (what the student suggests to improve } \\
\text { the teaching of philosophy in the } \\
\text { future) }\end{array}$ \\
\hline $\begin{array}{l}\text { 1) encourage students to take a more active } \\
\text { part in the development of the educational } \\
\text { process, stimulate students' motivation, their } \\
\text { self-analysis and involvement in the } \\
\text { educational process }\end{array}$ & $\begin{array}{c}\mathrm{A}-\text { satisfied } \\
\text { (on a percentage basis) } \\
\begin{array}{c}\mathrm{B}-\text { not satisfied } \\
\text { (on a percentage basis) }\end{array} \\
\mathrm{C}-\text { I doubt } \\
\text { (don't understand the question) }\end{array}$ & \\
\hline $\begin{array}{l}\text { 2) transparency and accessibility of the planned } \\
\text { course results }\end{array}$ & $\begin{array}{c}\text { A - satisfied } \\
\text { (on a percentage basis) } \\
\begin{array}{c}\mathrm{B}-\text { not satisfied } \\
\text { (on a percentage basis) }\end{array} \\
\begin{array}{c}\mathrm{C}-\text { I doubt } \\
\text { (don't understand the question) }\end{array}\end{array}$ & \\
\hline $\begin{array}{l}\text { 3) practical value of the results of the course of } \\
\text { philosophy (diagnosed variable) }\end{array}$ & $\begin{array}{c}\text { A - satisfied } \\
\text { (on a percentage basis) } \\
\begin{array}{c}\mathrm{B}-\text { not satisfied } \\
\text { (on a percentage basis) }\end{array} \\
\text { C - I doubt } \\
\text { (don't understand the question) }\end{array}$ & \\
\hline
\end{tabular}

Thank you for your cooperation in improving the quality of education in our University! 


\section{REFERENCES}

[1] Activities - The OECD Higher Education Programme // http://www.oecd.org/education/2030-project/

[2] Analitichnij oglyad. Visha osvita v Ukrayini: poryadok dennij dlya reform / KAS Policy Paper pid zag.red. Nikolayeva Y.B. (Rozd.4: Rozbudova vnutrishnoyi sistemi zabezpechennya yakosti vishoyi osviti Ukrayini u svitli oriyentiriv yevropejskogo standartu / Oleksandr Dlugopolskij, P. 28-34. [Analytical review. Higher education in Ukraine: an agenda for reform] [in Ukrainian]

[3] A. Bain, L. Zundans-Fraser. The Quality Illusion in Learning and Teaching. In: The Self-organizing University. Springer, Singapore, 2017.

[4] L. Bunce, A. Baird, S. E. Jones. The student-as-consumer approach in higher education and its effects on academic performance. Studies in Higher Education, 42(11): 1958-1978, 2017.

[5] Y.S. Chong, P.K. Ahmed. Student motivation and the 'feel good' factor: An empirical examination of motivational predictors of university service quality evaluation. Studies in Higher Education, Taylor \& Francis, 2015.

[6] I. Donnikova, V. Paulava. Intellectual culture of the modern manager // Science and Education a New Dimension. Pedagogy and Psychology, VII (86), Issue: 209, Nov. P. 22-27, 2019.

[7] Y. M. Dora, K. Kaniawati, N. Nurani. Service Quality, Student Satisfaction and Decision in Remaining Active to Study - Study at Private Universities in West Java. Universal Journal of Educational Research, 7(5A): 18-23, 2019.

[8] J. A. Douglas, A. Douglas, R. J. McClelland, et al. Understanding student satisfaction and dissatisfaction: an interpretive study in the UK higher education context, Studies in Higher Education, 40(2): 329-349, 2015.

[9] T. Dudun. Kartografichnij monitoring yakosti vishoyi osviti [Cartographic monitoring of the quality of higher education] / Visnik Kiyivskogo nacionalnogo universitetu im. T.G. Shevchenka. Geografiya. K., 2017. Vip. 3 (68)/4 (69). S. 122-126] [in Ukrainian]

[10] Dopovid Ukrayinskogo Institutu majbutnogo «Ukrayina 2030», Rozdil: Suchasnij stan osviti Ukrayini - Learning Nation [Report of the Ukrainian Institute of the Future "Ukraine - 2030", Section: The current state of education in Ukraine - Learning Nation]/ K.: kviten, 2019. 33 p. [in Ukrainian]

[11] K.M. Elliott, M.A. Healy. Key Factors Influencing Student Satisfaction Related to Recruitment and Retention. Journal of Marketing for Higher Education, 10(4): 1-11, 2001.

[12] Ch. Fadel, B. Trilling, M. Bialak. Four-Dimensional Education: The Competencies Learners need to succeed. Center for curriculum redesign, 2015.

[13] H. J. Green, M. Hood, D. L. Neumann. Predictors of student satisfaction with university psychology courses: A review Psychology Learning \& Teaching, 2015.
[14] G. Gachino, G.Worku. Learning in higher education: towards knowledge, skills and competency acquisition / International journal of educational management N 7. V33, pp. 1746-1770, 2019.

[15] N. C. Jackson. Managing for competency with innovation change in higher education: Examining the pitfalls and pivots of digital transformation / Business Horizons. Vol. 62, Issue 6, pp. 761-772, Nov.-Dec. 2019.

[16] Law of Ukraine No. 1556-VII on Higher Education of 1 July 2014. The Official Bulletin of the Verkhovna Rada of Ukraine. 2014. Nos. 37-38.

[17] V.J. Llorent, I. Zych, J.C. Varo-Millán. The skill of learning to learn at university. Proposal for a theoretical model. Educación XX1, 23(1), 297-318, 2020.

[18] R. Maxwell-Stuart, B. Taheri, A. S. Paterson, et al. Working together to increase student satisfaction: exploring the effects of mode of study and fee status, Studies in Higher Education, 43:8, 1392-1404, 2018.

[19] A. Nerubasska. K voprosu o vazhnosti prepodavaniya inzhenernoi etiki $\mathrm{v}$ ukrainskikh tekhnicheskikh vuzakh [Revisiting the Role of Teaching Engineering Ethics in the Ukrainian Technical higher Educational Institutions]// A.A. Nerubasska. Russia. St.-Petersburg: Globus scientific journal, 2015. pp. 37-42. [in Russian]

[20] A. Nerubasska. Filosofiya obrazovaniya: sistemno-sinergeticheskaya eksplikatsiya: monografiya [Education Philosophy: Systems Synergetic Explication: Monograph]// A.A. Nerubasska et al. Monograph. Poland. Opole: Publishing House WSZiA. 2015. [in Russian]

[21] V. Okulich-Kazarin. What Method of Learning do Media Students Prefer at Lectures: Auditory or Visual? Universal Journal of Educational Research, 8(6): 2660 - 2667, 2020.

[22] V. Okulich-Kazarin, M. Zhurba, et al. Three Characteristic Features of the East European Education services Market. Universal Journal of Educational Research, 8(4): 1549 1556, 2020.

[23] V. Okulich-Kazarin, M. Zhurba, O. Pagava, et al. Lecture method preferences, auditory or visual, of Ukrainian consumers of education services: a statistical analysis, International Journal of Education and Practice, 7(2): 54-65, 2019.

[24] V. Okulich-Kazarin, M. Zhurba, Y. Bokhonkova, et al. Three Scientific Facts about Ukrainian and Polish Law-students: Verification of statistical hypotheses about their Preferences of Learning at Lectures. European Journal of Contemporary Education, 8(3): 562-573, 2019.

[25] V. Paulava. Praktika formuvanya metakognityvnich navychok // Bulletine of the Conference «Morske pravo ta management», Odesa, 2019, P. 315-319. [The forming practice of metacognitive skills]. [in Ukrainian]

[26] PISA for development international seminar held in conjunction with the 48th meeting of the PISA governing board (PGB), Central Hall - Westminster, London, 2019.

[27] K. Schwab. The Fourth Industrial revolution, World Economic Forum, 2016 https://www.weforum.org/agenda/2016/01/the-fourth-indu strial-revolution-what-it-means-and-how-to-respond 
[28] P. Rose. Three lessons for educational quality in post-2015 goals and targets: Clarity, measurability and equity // International Journal of Educational Development. Vol. 40, Pp. 289-296, Jan. 2015.

[29] Standarti i rekomendaciyi shodo zabezpechennya yakosti v Yevropejskomu prostori vishoyi osviti (ESG). K.: TOV «CS», 2015. 32c. [Standards and recommendations for quality assurance in the European Higher Education Area (ESG).] [in Ukrainian]

[30] I.A. Kuzmenko et al. Usovershenstvovaniye uchebnogo protsessa $\mathrm{V}$ Odesskom natsionalnom meditsinskom universitete [Improvement of the Educational Process in the Odesa National Medical University]. Bulletine of the Conference "XVII -V.V. Podvysotskiy Readings". - Odesa National Medical University. - 2018. - pp. 57-58.
[31] Visha osvita i nauka: naukovo-analitichnij oglyad / Kiyiv. nac. un-t im. T. Shevchenka, Nauk. b-ka im. M. Maksimovicha, Inform.-bibliogr. vid.; [uporyad.: T. M. Byelousova, A. V. Kozonushenko; za zag. red. I.I. Tishenko; nauk. red. O. O. Serbin]. K.: 2018. № 6/7 (cherven-lipen). 86 p. [Higher education and science: scientific and analytical review] [in Ukrainian]

[32] Rozvitok sistemi zabezpechennya yakosti vishoyi osviti v Ukrayini: informacijno-analitichnij oglyad / Ukladachi: Dobko T., Zolotarova I., Kalashnikova S., Kovtunec V., Kurbatov S., Linova I., Lugovij V., Prohor I., Rashkevich Yu., Sikorska I., Talanova Zh., Finikov T., Sharov S.; za zag. red. S. Kalashnikovoyi ta V. Lugovogo. K.: DP «NVC «Prioriteti», 2015. 84 p. [Development of the quality assurance system of higher education in Ukraine: information-analytical review] [in Ukrainian] 